\title{
Pengaruh Bermain Bola Plastik Kecil terhadap Kemampuan Gerak Manipulatif Anak
}

\author{
Syarifah Mutmainah Van Gobel, Pupung Puspa Ardini, Icam Sutisna \\ Universitas Negeri Gorontalo \\ syarifahvabel@gmail.com
}

\begin{tabular}{l} 
Info Artikel \\
\hline Sejarah Artikel: \\
Diterima (Desember) (2019) \\
Disetujui (Januari) (2019) \\
Dipublikasikan (Januari) \\
(2019)
\end{tabular}

Keywords:

Bermain Bola Plastik Kecil, Gerak Manipulatif, Anak Usia Dini

\begin{abstract}
Abstrak
Penelitian ini dilakukan kaena rendahnyakemampuan anak dalam gerak manipulative. Tujuan penelitian ini untuk memperoleh data empirik tentang Pengaruh Bermain Bola Plastik Kecil Terhadap Kemampuan Gerak Manipulatif Anak. Metode penelitian yang digunakan yaitu penelitian kuantitatif dengan desain one group pretest posttest. Teknik pengumpulan data yang digunakan yaitu tes performance. Hasil penelitian menunjukan nilai rata-rata pretest atau sebelum diberikan perlakuan adalah 11,05 dan nilai rata-rata posttest setelah diberikan perlakuan adalah 36,80. Pengujian hipotesis dengan menggunakan statistik non parametrik dalam hal ini yaitu uji Wilcoxon. Dasar pengambilan keputusan pada uji Wilcoxon yaitu, jika nilai Asymp.sig.<0,05, Maka $\mathrm{H}_{1}$ diterima dan jika nilai Asymp.sig.> 0,05, Maka $\mathrm{H}_{1}$ ditolak dan berdasarkan output tes statistics, diketahui Asymp.sig.n(2-tailed) bernilai 0,000. Oleh karena nilai 0,000<0,05 maka hipotesis diterima.
\end{abstract}

\begin{abstract}
This research was conducted because of the low ability of children in manipulative motion. The purpose of this study was to obtain empirical data about the Effects of Playing Small Plastic Balls on Children's Manipulative Motion Capabilities. The research method used is quantitative research with one group pretest posttest design. Data collection techniques used are performance tests. The results showed the average value of the pretest or before treatment was 11.05 and the average value of the posttest after treatment was 36.80. Hypothesis testing using non-parametric statistics in this case is the Wilcoxon test. The basis for decision making in the Wilcoxon test is, if the Asymp.sig value <0.05, then H1 is accepted and if the Asymp.sig value> 0.05 , then $H 1$ is rejected and based on test output statistics, it is known asymp.sig.n (2-tailed) worth 0,000. Because the value is 0,000<0.05, the hypothesis is accepted.
\end{abstract}

\section{Pendahuluan}

Lempar tangkap bola merupakan kegiatan bermain yang menggunakan bola sebagai media. Kegiatan lempar tangkap bola ini seringkali diterapkan bagi anak usia 
dini dengan tujuan untuk mengembangkan kemampuan gerak manipulatif. Penelitian ini menggunakan media bola plastik kecil yang ringan dan tidak memberatkan bagi anak dalam bermain lempar tangkap bola di TK Abdi PKK kecamatan bolaang uki kabupaten bolaang mongondow selatan. Media bola kecil digunakan sebagai alat bantu untuk membantu mengembangkan kemampuan gerak manipulatif. Media bola kecil juga berfungsi sebagai rangsangan agar anak tertarik untuk melakukan aktivitas bermain. Anak di kelompok A adalah anak yang masih membutuhkan upaya pembinaan, bimbingan dan latihan untuk mencapai optimalisasi semua aspek perkembangan termasuk perkembangan motorik. Pada usia ini pembelajaran melalui bermain sangat mempengaruhi anak dalam memperoleh berbagai keterampilan motorik termasuk keterampilan gerak manipulatif sehingga keterampilan gerak manipulatif anak dalam melempar dan menangkap bola menjadi berkembang.

Berdasarkan hasil observasi awal yang dilakukan di TK abdi PKK desa popodu kecamatan bolaang uki kabupaten bolaang mongondow selatan pada bulan agustus yang berjumlah 20 anak, terdapat 11 orang anak yang kemampuan motorik kasar dalam melakukan gerak manipulatif terutama dalam gerakan melempar dan menangkap bola kecil masih perlu dikembangkan secara optimal. Peneliti menemukan adanya beberapa masalah yang terdapat pada diri anak yaitu, gerakan manipulatif anak dalam melempar bola belum terarah dengan baik, arah lemparan belum tepat dan anak belum mampu menangkap bola dengan baik. Peneliti mengharapkan dengan adanya bermain bola plastik kecil pada TK abdi PKK desa popodu kecamatan bolaang uki kabupaten bolaang mongondow selatan dapat melatih kemampuan motorik anak khususnya pada gerakan manipulatif.

Berdasarkan permasalahan yang telah dijelaskan maka peneliti merasa perlu untuk melakukan penelitian tentang bermain bola plastik kecil terhadap kemampuan gerak maipulatif anak di TK Abdi PKK Kecamatan Bolaang Uki Kabupaten Bolaang Mongondow Selatan.

\section{Metode Penelitian}

Metode penelitian yang digunakan dalam penelitian ini adalah metode eksperimen. Menurut sugiyono (2015 :107) metode penelitian eksperimen merupakan metode 
penelitian yang digunakan untuk mencari pengaruh perlakuan tertentu terhadap yang lain, dalam kondisi yang terkendalikan. Desain penelitian yang digunakan dalam penelitian ini adalah one grup pretest-posttest design.

Tabel 3.1 bagan desain one-group pretest-posttes design

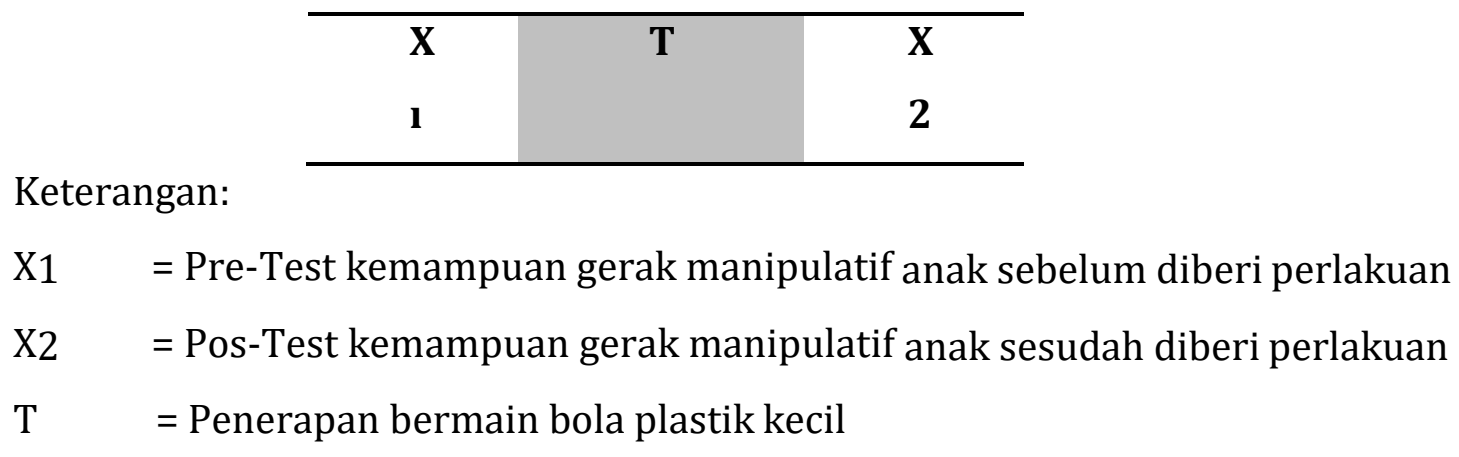

\section{Hasil Penelitian dan Diskusi}

\section{Hasil}

Dari keseluruhan data yang dianalisis, diperoleh data pretest rata-rata 11. Hal ini menunjukan bahwa kemampuan gerak manipulatif anak masih belum maksimal karena belum menggunakan permainan bola plastik kecil. Kemudian untuk nilai rata-rata posttest yaitu 37 sehingga dapat dikatakan bahwa bermain bola plastik kecil mempengaruhi kemampuan gerak manipulatif anak.

Data dengan hasil nilai signifikan 0,000. Dalam hal ini nilai signifikan data kurang dari 0,05 yang berarti data yang diperoleh dari hasil penelitian berdistribusi tidak normal. Selanjutnya untuk melakukan pengujian hipotesis digunakan statistic non parametrik, dalam hal ini yakni uji Wilcoxon yaitu suatu metode pengujian yang digunakan untuk mengetahui perbedaan rata-rata dan hasil Pretest dan data hasil Posttest. Dasar pengambilan keputusan pada uji Wilcoxon yaitu:

1. Jika nilai Asymp.sig.<0,05, Maka H1 diterima

2. Jika nilai Asymp.sig.> 0,05, Maka H1 ditolak

Berdasarkan output Tes Statistics, diketahui Asymp.sig.n(2-tailed) bernilai 0,000. Oleh karena nilai 0,000 $<0,05$ maka hipotesis diterima. Dengan demikian, hipotesis penelitian menyatakan bahwa terdapat pengaruh bermain bola plastik kecil terhadap kemampuan gerak manipulatif anak kelompok A TK abdi PKK Desa Popodu Kecamatan Bolaang Uki Kabupaten Bolaang Mongondow Selatan. 
Berdasarkan uji normalitas menggunakan rumus Lilieforse diperoleh uji normalitas

\section{Diskusi}

Menurut montolalu (2009:739) lempar tangkap bola merupakan salah satu permainan yang menggunakan bola sebagai media. Lempar tangkap adalah gerakan yang mengarahkan benda/bola yang melambung atau menggulir. Permainan lempar tangkap bola ini menggunakan kekuatan tangan kanan dan kiri yang bertujuan untuk dapat melatih gerakan manipulatif anak usia dini.

Pada hasil penelitian sebelumnya, dinyatakan bahwa bermain bola plastik kecil mempengaruhi kemampuan gerak manipulatif anak usia dini. Hal tersebut sejalan dengan teori behaviorisme yang menjelaskan bahwa belajar merupakan bentuk perubahan yang dialami siswa dalam hal kemampuannya untuk bertingkah laku dengan cara yang baru sebagai hasil interaksi stimulus dan respons. Dalam pembelajaran diperlukan adanya drill atau biasa disebut dengan latihan,dimana suatu teknik yang dapat membantu anak menguasai keterampilan secara tepat dalam perilaku yang cepat dan otomatik. Dengan melaksanakan kegiatan latihan anak akan lebih terampil dan berprestasi dalam bidangnya.

Dari hasil penelitian menggambarkan bahwa terdapat perbedaan antara kemampuan gerak manipulatif sebelum bermain bola plastik kecil dan sesudahnya, dapat dibuktikan dengan jumlah nilai yang diperoleh yakni nilai rata-rata kemampuan gerak manipulatif. sebelum bermain bola plastik kecil adalah 11,05, sedangkan nilai rata-rata kemampuan gerak manipulatif sesudah bermain bola plastik kecil adalah 36,80. Hasil tersebut membuktikan perbedaan signifikan sebelum dan sesudah pemberian perlakuan.

\section{Simpulan}

Berdasarkan hasil penelitian yang telah dijelaskan pada pembahasan sebelumnya dapat ditarik kesimpulan, yaitu terdapat pengaruh bermain bola plastik kecil terhadap kemampuan gerak manipulatif anak kelompok A TK abdi PKK Desa Popodu Kecamatan Bolaang Uki Kabupaten Bolaang Mongondow Selatan. Dasar pengambilan keputusan pada uji Wilcoxon yaitu: Jika nilai Asymp.sig.< 0,05, Maka H1 diterima dan jika nilai Asymp.sig.> 0,05, Maka H1 ditolak. Berdasarkan output Tes Statistics, diketahui Asymp.sig.n(2-tailed) bernilai 0,000. Oleh karena nilai 0,000<0,05 
maka hipotesis diterima. Dengan demikian, hipotesis penelitian menyatakan bahwa terdapat pengaruh bermain bola plastik kecil terhadap kemampuan gerak manipulatif anak kelompok A TK abdi PKK Desa Popodu Kecamatan Bolaang Uki Kabupaten Bolaang Mongondow Selatan. Pelaksanakan dapat dikemukakan saran-saran berikut ini: 1) Bagi Guru TK, untuk menstimulasi perkembangan motorik kasar khususnya kemampuan gerak manipulatif hendaknya bervariasi dan guru dapat mengembangkan RKH sesuai dengan kurikulum PAUD yang ditentukan oleh dinas dan memperaktekan, saranan dan prasarana hendaknya digunakan dengan efektif sehingga tidak rusak menganggur. 2) Bagi anak, agar selalu percaya diri dan konsentrasi ketika mempraktekan teknik yang diajarkan oleh guru saat pembelajaran berlangsung. Guru harus berperan pembelajaran sebagai pedoman dalam menyelenggarakan kegiatan sehingga tujuan pembelajaran di sentra persiapan kelompok B2 Taman Kanak-kanak Islam Terpadu Raudhatul Jannah Kota Cilegon tahun pelajaran 2013/2014 dapat tercapai. 3) Dalam melakukan proses pembelajaran, selain melakukan persiapan pelaksanaan proses pembelajaran melalui lesson plan (Rencana Kegiatan Mingguan dan Rencana Kegiatan Harian), yang harus dilakukan guru di Sentra persiapan adalah penataan lingkungan main, penyambutan kedatangan anak, melakukan main pembukaan (pengalaman gerakan kasar), melakukan transisi sebelum memulai kegiatan inti, dalam kegiatan inti yang harus diperhatikan adalah pijakan Pengalaman sebelum anak main, pijakan Pengalaman selama anak main, pijakan pengalaman setelah main (Reclling) dan kegiatan penutup. 4) Pembelajaran di sentra persiapan dapat meningkatkan kemampuan dasar kognitif anak TKIT Raudhatul Jannah. Hal ini dapat dilihat dari nilai rata-rata kemampuan dasar kognitif yang diperoleh dari Siklus I yang perlu perhatian mencapai $14 \%$, mulai berkembang $51 \%$, yang berkembang sesuai harapan 21,5 \% dan yang berkembang sangat baik mencapai 13,5 \%, pada Siklus II yang perlu perhatian menurun menjadi 1 $\%$, mulai berkembang menurun menjadi $17 \%$, yang berkembang sesuai harapan meningkat menjadi $64,5 \%$ dan yang berkembang sangat baik meningkat menjadi 17,5 \% dan pada siklus III ada perkembangan yang sangat baik yaitu tidak ada lagi yang perlu perhatian, mulai berkembang menurun menjadi $5 \%$, berkembang sesuai harapan $27 \%$ dan yang berkembang sangat baik meningkat tajam menjadi $68 \%$.

\section{Daftar Pustaka}

Anwar, Desy. 2003. Kamus Lengkap Bahasa Indonesia. Surabaya :Amelia 
Budiningsih, Asri. 2005. Belajar Dan Pembelajaran. Jakarta :Rineka cipta.

Coughun, A Pamela. 2000. Menciptakan Kelas Yang Berpusat Pada Anak. Children's resources international Carol, S Catron. 1999. Early Childhood Curriculum second Education A Creative Play Model. Prentice- Hall,inc.

Djumidar, 2005. Dasar-Dasar atletik. Jakarta: Universitas Terbuka Gafur, Abd. 1987. Desain Instruksional suatu langkah sistematis penyusunan pola dasar kegiatan belajar dan mengajar. Bandung : Tarsito

Hartinah, Sitti. 2011. Pengembangan Peserta Didik, Bandung : PT refika aditama. Kriyantono, Rachmat 2014. Teknik Praktis Riset 